\title{
Serum zinc levels in hospitalized children with acute lower respiratory infections in the north-central region of Nigeria
}

\author{
Rasheedat Mobolaji Ibraheem ${ }^{1}$, AbdulWahab Babatunde Rotimi Johnson ${ }^{2}$, \\ Aishatu Ahmed Abdulkarim ${ }^{3}$, Sikiru A. Biliaminu ${ }^{4}$.
}

1. Department of Paediatrics \& Child Health, University of Ilorin Teaching Hospital, PMB 1515, Ilorin, Kwara State, Nigeria

2. (Pulmonology \& Infectious Disease), Department of Paediatrics \& Child Health, University of Ilorin Teaching Hospital, PMB 1515, Ilorin, Kwara State, Nigeria

3. Paediatrics/Consultant (Adolescent Medicine, Pulmonology \& Infectious Disease), University of Ilorin Teaching Hospital, PMB 1515, Ilorin, Kwara State, Nigeria

4. Consultant Chemical Pathologist, Department of Chemical Pathology and Immunology, University of Ilorin

Teaching Hospital, PMB 1515, Ilorin, Kwara State, Nigeria

\begin{abstract}
Background: Macronutrient deficiency has continued to attract significant research interest, where as the import of micronutrients like zinc has only recently become the focus of interest. Thus against the background of a dearth of data on zinc levels in Nigerian children with Acute Lower Respiratory Infection (ALRI), this study was carried out in Ilorin, Nigeria to determine the serum zinc levels in hospitalized children with ALRI.

Methodology: A comparative cross-sectional hospital based study involving 120 children aged two months to five years with ALRI recruited as subjects, and 120 age- appropriate controls without ALRI was carried out. Socio-demographic, clinical and laboratory data were obtained. The serum zinc was analyzed with a Jenway ${ }^{\mathrm{TM}}$ spectrophotometer after an initial preparation with the QuantiChrom ${ }^{\mathrm{TM}}$ zinc assay kit.

Results: The male/ female ratio was 1.6:1. The mean (SD) serum zinc level in subjects with ALRI of 18.7(11.8) $\mathrm{\mu g} / \mathrm{dl}$ was significantly lower than the corresponding value of $53.1(18.5) \mu \mathrm{g} / \mathrm{dl}$ recorded in the controls, $\mathrm{p}=0.001$. The prevalence of $98.3 \%$ for low serum zinc levels recorded in children with ALRI was significantly higher than that recorded in controls of $64.2 \%, \mathrm{p}=0.001$.

Conclusion: Low serum zinc levels are significantly associated with ALRI. There is a need to determine whether hospitalized children managed for ALRI might benefit from post discharge zinc supplementation.

African Health Sciences 2014;14(1): 136-142 http://dx.doi.org/10.4314/ahs.v14i1.21
\end{abstract}

\section{Introduction}

The incidence, severity and case fatality of ALRI, especially pneumonia is adversely affected by malnutrition which has been highlighted in earlier reports. ${ }^{1-3}$ Indeed, malnutrition has been identified as an important determinant of ALRI-related mortality. ${ }^{3}$ The vulnerability of malnourished children to ALRI in developing countries has been ascribed to a reduction in cellular immunity and possibly zinc deficiency. ${ }^{4,5}$

Zinc is a trace element with a direct anti-viral activity and a demonstrable effect on immune-mediated production of interferon. ${ }^{6,7}$ Also, zinc prevents pathogens from gaining entry into cells and hinders

\section{Correspondence author: \\ Rasheedat Mobolaji Ibraheem \\ Private Mail Bag 1515 \\ Ilorin, Kwara State, Nigeria \\ Tel:+2348033704168, +2348185415491 \\ E-mail: rasheedahbidmus@yahoo.com}

their intra-cellular multiplication. ${ }^{6,7}$ Zinc deficiency decreases the ability of the body to respond to infection, and also adversely affects both cell-mediated and humoral immune responses. ${ }^{6}$ The impaired immunocompetence due to low zinc states would not only enhance the establishment of a particular infection but is also associated with a reduction in the clearance of infectious agents. ${ }^{6}$

The zinc concentration in plasma, hair and urine can be assessed in detecting zinc deficient states but measuring the serum zinc level has been recommended as an appropriate biomarker. ${ }^{8}$ The serum concentration is affected by factors such as age, dietary intake and infections. $^{8}$

Children with pneumonia have been found to have lower blood zinc levels as compared to uninfected children. ${ }^{5,9,10}$ Even in well nourished children with ALRI, serum zinc levels have been found to be lower compared with the uninfected. ${ }^{5,10}$ Trials of zinc supplements also constitute a reliable method of assessing the health 
consequences of zinc deficiency. ${ }^{7}$ In 2009 , a systematic review of studies evaluating preventive effects of zinc supplementation on the morbidity burden of ALRI noted an overall reduction of $15-21 \%$ in the incidence of ALRI among zinc-supplemented preschool children. ${ }^{11}$

Although some interventional studies on zinc supplementation have been carried out in the Gambia and Burkina Faso in West Africa, children with ALRI were not studied. ${ }^{12,13}$ Furthermore, while there have been studies on serum zinc levels in children in some parts of Nigeria, there is a paucity of surveys in which children with ALRI were targeted. ${ }^{14} \mathrm{~A}$ comparative cross-sectional study was therefore done to determine the serum zinc levels of children aged two months to five years with ALRI and the corresponding levels in controls without ALRI.

\section{Materials and Method}

The study was conducted in the Emergency Paediatric Unit (EPU) and the Paediatric Medical Ward of the University of Ilorin Teaching Hospital (UITH), located in Ilorin South Local Government Area (LGA) of Kwara State. Ilorin is the capital city of Kwara State, situated in the North Central geopolitical zone of Nigeria.

Using the formula $\left(2 z^{2} \mathrm{pq} / \mathrm{d}^{2}\right)^{15}$ with a tolerable margin of error of $10 \%$ and a prevalence of $15.8 \%$ from a previous study, ${ }^{2}$ the minimum sample size of 102 was calculated however, 120 subjects were recruited.

Children aged between two months and up to five years with an admission diagnosis of either pneumonia or bronchiolitis were recruited as subjects. The diagnosis of pneumonia was based on the presence of acute cough, fever, breathlessness, age-related tachypnoea, and auscultatory findings of one or more of reduced breath sound intensity, bronchial breath sounds and crepitations. ${ }^{1}$ Bronchiolitis was diagnosed based on the presence of cough, fever, wheezing and dyspnoea, associated with bilateral polyphonic expiratory rhonchi, inspiratory crepitations and clinical/radiographic features of hyperinflation. ${ }^{1}$ Controls were children attending the Paediatrics Out-Patient Clinic for routine follow-up without any underlying cardiac, haematological or infectious co-morbidity. The subjects were age-matched $\{ \pm$ three months $\}$ and gender matched with the controls.

Children who had diarrhoea in the preceding one month, severe form of malnutrition (marasmus, kwashiorkor and marasmic-kwashiorkor), a history and evidence of hepatic disease, or history of use of zinc supplements in the past one month were excluded from the study. A history of either antecedent use of medication or hospital visit was used in excluding the use of zinc supplements. Ethical approval was granted by the Ethics and Research Committee of the UITH. Onehundred and twenty subjects were recruited for each of the study and control groups between April 2010 and July 2010.

A semi-structured questionnaire was administered to each child's caregiver to collect socio-demographic and clinical data after obtaining an informed consent. Socioeconomic index scores were awarded to the occupations and educational attainments of their parents using the Oyedeji socio-economic classification scheme. ${ }^{16}$ The mean of four scores (two for the father and two for the mother) approximated to the nearest whole number was the social class assigned to the child as proposed by Oyedeji. ${ }^{16}$ Chest radiographs were obtained in all subjects. Blood samples were collected from subjects and appropriate controls for estimating the serum zinc, total protein, albumin and an acute-phase reactant protein, namely the $\mathrm{C}$-reactive protein (CRP). The CRP estimation was done to provide an objective laboratory evidence for the absence of an ongoing inflammation in the control at the time of the recruitment. ${ }^{17}$

Using strict aseptic techniques, two millilitres of blood was collected via venepunture, immediately aliquoted into a plain bottle, and then allowed to clot. Serum samples were obtained by centrifuging the clotted blood sample at $3000 \mathrm{rpm}$ for ten minutes in a benchtop centrifuge. The sera obtained were transferred into sterile plastic tubes and stored immediately at $-20^{\circ} \mathrm{C}$, till it was ready to be analyzed when the sera were thawed followed by batch analysis. Unhaemolyzed sera were used, and any serum which was neither clear nor colourless was discarded. The serum zinc analysis was done with a Jenway ${ }^{\mathrm{TM}}$ spectrophotometer 6300 model (Jenway Limited, Dunmow, Essex, United Kingdom) for measuring optical density at $425 \mathrm{~nm}$, after an earlier preparation with the QuantiChrom ${ }^{\mathrm{TM}}$ Zinc colorimetric assay kit (Bioassay Systems, Hayward, California, US A). ${ }^{18}$ For the zinc assay, $\mathrm{Zn}^{2+}$ Standard $(10 \mu \mathrm{M}), 50 \mu$ l of water, Sample and Sample Blank $(50 \mu \mathrm{L}$ sample $+2 \mu \mathrm{L}$ EDTA) were transferred into wells of a clear bottom 96-well plate. ${ }^{18}$ Subsequently $200 \mu \mathrm{L}$ of the working reagent was added to each well and then mixed by tapping the plate lightly. The resulting solution was allowed to incubate for 30 minutes at room temperature. ${ }^{18}$ The optical density 
(OD) was read at 420-426nm (peak absorbance at 425 $\mathrm{nm}) \cdot{ }^{18}$ For this study, a value of $57 \mu \mathrm{g} / \mathrm{dl}$ was used as the lower cut-off for low serum zinc concentrations. ${ }^{17}$ Also, since zinc is transported in plasma bound to albumin, the concomitant serum albumin and total protein level were determined. The total protein, albumin and CRP assay kits (Agappe Diagnostics Limited, Kerala, India) were used for determining the serum protein levels.

Data analysis was with the SPSS 16 software package. Frequencies, proportion, means and standard deviations were calculated. The Chi-square and Student's t-tests were used to identify significant differences for categorical and continuous variables respectively.

\section{Results}

A total of 120 under-five children with ALRI were recruited as subjects, and an additional 120 age-and gender-matched children were used as controls. The mean (SD) age of the children with ALRI was 20.8(17.6) months compared with a corresponding mean (SD) of 19.8(15.4) months for control. No statistical difference was shown between the age of the subjects and controls $(p=0.649)$. The male: female (M: F) ratio for the subjects and controls was 1.6:1. Infants ( $<12$ months) represented $37.5 \%$ of the children with ALRI (Table I).

Table 1: Age and gender distribution of the children with ALRI

\begin{tabular}{lllll}
\hline $\begin{array}{l}\text { Age group } \\
\text { (months) }\end{array}$ & $\begin{array}{l}\text { Male } \\
\mathbf{n}(\boldsymbol{\%})\end{array}$ & $\begin{array}{l}\text { Female } \\
\mathbf{n}(\%)\end{array}$ & Total & Percentage \\
\hline $2-<12$ & $24(20.0)$ & $21(17.5)$ & 45 & 37.5 \\
$12-<24$ & $19(15.8)$ & $11(9.2)$ & 30 & 25.0 \\
$24-<36$ & $13(10.8)$ & $10(8.3)$ & 23 & 19.1 \\
$36-<48$ & $6(5.0)$ & $0(0.0)$ & 6 & 5.0 \\
$48-<60$ & $11(9.2)$ & $5(4.2)$ & 16 & 13.4 \\
\hline Total & $\mathbf{7 3 ( 6 0 . 8 )}$ & $\mathbf{4 7 ( 3 9 . 2 )}$ & $\mathbf{1 2 0}$ & $\mathbf{1 0 0}$ \\
\hline
\end{tabular}

Table 2 shows the socio-economic class and maternal educational level of the subjects and the control groups were not significantly different, each $p>0.05$.

Table 2: Socio-demographic characteristics of subjects and controls

\begin{tabular}{lllll}
\hline Parameter & $\begin{array}{l}\text { ALRI cases } \\
\mathbf{n = 1 2 0}(\mathbf{0})\end{array}$ & $\begin{array}{l}\text { Control } \\
\mathbf{n}=\mathbf{1 2 0}(\mathbf{0})\end{array}$ & $\chi^{2}$ & $\mathrm{P}$ \\
Gender & $73(60.8)$ & $73(60.8)$ & & \\
Male & $47(39.2)$ & $47(39.2)$ & - & \\
Female & & & & \\
Socio-economic class & $10(8.3)$ & $10(8.3)$ & & \\
I & $47(39.2)$ & $44(36.7)$ & & 0.453 \\
II & $33(27.5)$ & $45(37.5)$ & $3.668^{*}$ & \\
III & $28(23.3)$ & $19(15.8)$ & & \\
IV & $2(1.7)$ & $2(1.7)$ & & \\
V & $14(11.7)$ & $17(14.2)$ & & \\
Maternal educational status & $20(16.7)$ & $23(19.2)$ & $2.837 *$ & \\
None & $43(35.8)$ & $31(25.8)$ & & \\
Primary & $43(35.8)$ & $49(40.8)$ & & \\
Secondary & & & \\
Post Secondary & & & \\
\hline
\end{tabular}

Three different ALRI diagnoses were commonly made among the subjects recruited; 95 (79.2\%) children had bronchopneumonia, $16(13.3 \%)$ had lobar pneumonia and $9(9.5 \%)$ had bronchiolitis. The ratio of bronchiolitis: lobar pneumonia: bronchopneumonia was 1:1.8:10.7
The mean (SD) weight of the children with ALRI was $9.2(3.2) \mathrm{kg}$ and the corresponding value in the control was $11.0(3.6) \mathrm{kg}$. The mean (SD) height of the children with ALRI was $76.9(17.4) \mathrm{cm}$ while the corresponding height in the control was $82.5(18.5) \mathrm{cm}$. Table 3 shows the anthropometry of the subjects and control. 
Table 3: Anthropometry of the subjects and controls

\begin{tabular}{|c|c|c|c|c|}
\hline Anthropometry* & $\begin{array}{c}\text { ALRI subject } \\
n(\%)\end{array}$ & $\begin{array}{c}\text { Control } \\
\mathrm{n}(\%)\end{array}$ & $\chi^{2}$ & $\mathrm{p}$ \\
\hline weight-for-age & & & & \\
\hline $\begin{array}{l}\text { percentage }(\%) \\
=80\end{array}$ & $41(34.2)$ & $13(10.8)$ & 18.730 & 0.001 \\
\hline $\begin{array}{l}>80 \\
\text { height-for-age }\end{array}$ & $79(65.8)$ & $107(89.2)$ & & \\
\hline $\begin{array}{l}\text { percentage }(\%) \\
<95\end{array}$ & $55(45.8)$ & $30(25.0)$ & 11.390 & 0.001 \\
\hline $\begin{array}{l}\geq 95 \\
\text { weight-for-height }\end{array}$ & $65(54.2)$ & $90(75.0)$ & & \\
\hline $\begin{array}{l}\text { percentage }(\%) \\
\geq 90 \\
\geq 90\end{array}$ & $\begin{array}{l}56(46.7) \\
64(53.3)\end{array}$ & $\begin{array}{l}36(30.0) \\
84(70.0)\end{array}$ & 7.051 & 0.008 \\
\hline
\end{tabular}

Table 4 shows the mean serum zinc level in subjects with ALRI was significantly lower than the corresponding value for controls $(\mathrm{p}=\mathbf{0 . 0 0 1})$. The mean serum albumin in ALRI cases was significantly lower than the corresponding value in the controls, $\mathrm{p}=\mathbf{0 . 0 0 1}$ while there was no significant difference between the mean total serum protein levels of the subjects and controls $(p=0.333)$.

Table 4: Serum zinc levels and the related laboratory parameters in subjects and controls

\begin{tabular}{|c|c|c|c|c|}
\hline Parameter & $\begin{array}{c}\text { ALRI } \\
\text { subjects } \\
(\mathrm{n}=120)\end{array}$ & $\begin{array}{l}\text { Controls } \\
(n=120)\end{array}$ & $\mathrm{t}$ & $\mathrm{p}$ \\
\hline $\begin{array}{l}\text { Serum zinc }(\mu \mathrm{g} / \mathrm{dl}) \\
\text { Range }\end{array}$ & 4.1-94.1 & 20.3-110.9 & & \\
\hline $\begin{array}{l}\text { Mean }(\mathrm{SD}) \\
\text { Serum total protein }(\mathrm{g} / 1)\end{array}$ & $18.7(11.8)$ & $53.1(18.5)$ & 17.173 & 0.001 \\
\hline $\begin{array}{l}\text { Range } \\
\text { Mean (SD) }\end{array}$ & $\begin{array}{l}43.0-105.0 \\
72.5(13.2)\end{array}$ & $\begin{array}{l}47.0-100.0 \\
74.1(12.3)\end{array}$ & -0.971 & 0.332 \\
\hline $\begin{array}{l}\text { Serum albumin }(\mathrm{g} / \mathrm{l}) \\
\text { Range } \\
\text { Mean (SD) } \\
\text { Serum CRP (mg/1) }\end{array}$ & $\begin{array}{l}27.0-56.0 \\
39.5(6.6)\end{array}$ & $\begin{array}{l}31.0-58.0 \\
44.2(7.3)\end{array}$ & -5.232 & 0.001 \\
\hline $\begin{array}{l}\text { Range } \\
\text { Mean (SD) }\end{array}$ & $\begin{array}{c}1.2-74.0 \\
29.5(18.9)\end{array}$ & $\begin{array}{l}0.9-7.0 \\
3.2(1.8)\end{array}$ & 15.175 & 0.001 \\
\hline
\end{tabular}

Table 5 shows that 118 (98.3\%) subjects in the ALRI category had a low serum zinc status which was significantly more that the corresponding value in the controls of $77(64.2 \%),(p=0.001)$. Using a student t-test, the mean serum zinc levels of $17.6 \pm 7.7 \mu \mathrm{g} / \mathrm{dl}$ among the ALRI cases who had low serum zinc status differed significantly from the corresponding value of
$39.6 \pm 10.0 \mu \mathrm{g} / \mathrm{dl}$ recorded for the controls $(t$ value $=$ -17.304. $\mathrm{p}=\mathbf{0 . 0 0 0})$. On the other hand, for those with normal zinc status, the mean serum zinc levels among the children with ALRI were comparable with the corresponding values in the controls $(86.6 \pm 10.4$ $\mu \mathrm{g} / \mathrm{dl}$ vs $70.4 \pm 11.8 \mu \mathrm{g} / \mathrm{dl}$ respectively, $t$ value $=1.903$, $p=0.064)$.

Table 5: Zinc status of the study population

\begin{tabular}{lccccc}
\hline \multicolumn{1}{c}{ Zinc status } & $\begin{array}{c}\text { ALRI cases } \\
\mathbf{n}(\boldsymbol{\%})\end{array}$ & $\begin{array}{c}\text { Controls } \\
\mathbf{n}(\%)\end{array}$ & Total & OR (95\%C.I.) & P \\
\hline Low serum & $118(98.3)$ & $77(64.2)$ & 195 & $32.6(7.8-140.0)$ & $\mathbf{0 . 0 0 1}$ \\
zinc & $2(1.7)$ & $43(35.8)$ & 45 & & \\
$\begin{array}{l}\text { Normal serum } \\
\text { zinc }\end{array}$ & 120 & 120 & 240 & & \\
\hline
\end{tabular}

OR- Odds ratio CI- 95\% confidence interval 


\section{Discussion}

The preponderance of infants and toddlers aged less than two years amongst the ALRI subjects is in accord with earlier observations. tion of a stepwise decrease in the age-specific disease burden with increasing age is consistent with those of earlier reports." The fact that infants and toddlers constituted the majority may be due to the earlier reported susceptibility of this age group to frequent multiple viral upper respiratory infections. ${ }^{1}$ Clearly, this can be ascribed to the evolving immunity to the wide spectrum of potential pathogens including viruses. ${ }^{1}$ Indeed, earlier reports had identified infancy as a particularly vulnerable age group for childhood ALRI. ${ }^{19,20}$

Another relevant demographic observation in the present study was an overall male preponderance which is consistent with the findings in several earlier reports ${ }^{1,19,20}$ in which the male gender was found to be a significant risk factor for ALRI. While this may reflect the trend in the UITH paediatric consultations, ${ }^{21}$ the current male gender skew may not be completely devoid of a selection pool bias in view of the societal importance attached to the male child. ${ }^{22}$ The tendency therefore is for caregivers to give a more prompt attention to the ill male child and hence a higher hospital presentation. $^{23,24}$

In the current study, the finding of lower serum zinc levels in the children with ALRI compared with the controls is consistent with those of earlier reports emanating from India and Bangladesh. 5,9,10,25 However, the magnitude of the relative differences in serum zinc levels (1.4 to 2.2 times) between the children with ALRI and the controls in these earlier reports s, $^{5,10,25}$ is less than that of the current study in which the difference was almost thrice what obtained in the cases. The lower magnitude of serum zinc level differences between the subjects with ALRI and the controls in these earlier reports compared to the corresponding findings of the present study may be ascribed to limited sample sizes of those earlier surveys. ${ }^{5,910,25}$ None of these earlier studies ${ }^{5,9,10,25}$ had a subject pool of more than 50 children which contrasts with the subject pool of 120 in the current study.

In addition, the lower magnitude of differences in serum zinc level between the ALRI subjects and controls in the earlier reports ${ }^{5,9,10,25}$ may also be ascribed to a better underlying nutritional status of subjects in these reports. This is underscored by the appropriate weight for height percentage identified in $86-100 \%$ of the children with ALRI. This contrasts with the corresponding value of $53.3 \%$ in the present study.

Similarly, the $98.3 \%$ prevalence of low serum zinc status in the subjects with ALRI in the present study differs remarkably from the reported $56.0 \%{ }^{10}$ and $54.0 \%{ }^{5}$ in some of the earlier studies. The higher prevalence found in the controls of the current study compared to those of the controls of earlier reports from South East Asia by Kumar $e t a l^{10}$ in India and Shakur et a ${ }^{5}$ in Bangladesh is in accord with the above mentioned 'hypothesis' of a better nutritional status of subjects in those earlier reports.

The high prevalence of low serum zinc status in the local paediatric population (as reflected by the high prevalence in the controls) may be partly explained by the quality of the local staples in Ilorin. The common staple food in the local population and its environs comprise yam, maize and cassava, all of which have high phytates and fibre contents with the potential import of inhibiting the absorption and utilization of zinc. . $^{1426}$ Also, animal-rich sources of zinc such as meat, fish and poultry are consumed in limited quantity because of cost-related non-affordability of these foodstuff by the local population. ${ }^{26}$

The significantly higher prevalence of low serum zinc status in children with ALRI (compared with controls) may be clearly attributed to a pre-existing zinc deficiency state with its attendant negative effects on the immune status. ${ }^{6}$ Zinc is an essential factor for the development and sustenance of the human immune system which is recruited during an infection to prevent pathogens from gaining access into cells. ${ }^{6}$ Clearly, all the anti-infective deployment of this trace element may further deplete the zinc levels during an episode of ALRI. It has also been suggested that the low serum zinc levels identified during ALRI is mediated by interleukins and tumour necrosis factor-alpha (TNF-a) as part of an infectionrelated set of metabolic response known as acute phase reaction. ${ }^{6}$ The possible validity of this 'hypothesis' may explain the much lower serum zinc levels in the children with ALRI compared with the controls.

The significantly lower serum albumin levels identified in children with ALRI compared with the controls in the present study is not surprising and could be attributed to the fact that most of the serum zinc is transported bound to albumin. ${ }^{27}$ Therefore, depletion in serum zinc state present during an episode of ALRI would also 
be associated with depletion in serum albumin levels. Furthermore, the protein-rich inflammatory exudate associated with the pneumonic process may also partly account for the lower serum albumin levels in the subjects with ALRI in the present study.

\section{Conclusion}

The children with ALRI had lower serum zinc levels than the control and the prevalence of low serum zinc status in children with ALRI is high. Thus, there is a need to determine whether hospitalized children managed for ALRI might benefit from zinc supplementation as an adjunct to treatment as well as post discharge. Limitations include lack of knowledge of the pre-morbid zinc status of the children with ALRI, and the low number of patient in our study, as evidenced by the wide confidence interval of the odds ratio. Despite the fact that subjects and control were age- and gendermatched, they were not matched with respect to their nutritional status during recruitment which would have yielded a better comparison. Also, the hospital-based (tertiary institution) nature of the study precludes a true reflection of the population however the results will serve as a step in the right direction. Therefore a longitudinal study with a larger sample size is needed to confirm these findings.

The project was self-sponsored and the authors declare that there are no conflicts of interest.

\section{References}

1. Johnson WBR, Aderele WI, Osinusi K, Gbadero D. Acute lower respiratory infections in hospitalised urban pre-school Nigerian children: a clinical overview. Afr J Med Med Sci 1994;23(2):127-38.

2. Fagbule D, Parakoyi DB, Spiegel R. Acute respiratory infections in Nigerian children: Prospective cohort study of incidence and case management. J Trop Pediatr 1994;40:279-84.

3. Johnson AWBR, Osinusi K, Aderele WI, Gbadero DA, Olaleye O, Adeyemi-Doro F. Etiologic agents and outcome determinants of community-acquired pneumonia in urban children: a hospital-based study. J Natl Med Assoc 2008;100(4):370-85.

4. Zaman K, Baqui AH, Yunus M, Sack RB, Bateman OM, Chowdhury HR, et al. Association between nutritional status, cell-mediated immune status and acute lower respiratory infections in Bangladeshi children. Eur J Clin Nutr 1996;50(5):309-14.

5. Shakur MS, Malek MA, Bano N, Islam K. Zinc sta- tus in well nourished Bangladeshi children suffering from acute lower respiratory infection. Indian Pediatr 2004;41(5):478-81.

6. Shankar AH, Prasad AS. Zinc and immune function: the biological basis of altered resistance to infection. Am J Clin Nutr 1998;68(2 Suppl):447S-63S.

7. International Zinc Nutrition Consultative Group. Assessment of the risk of zinc deficiency in populations and options for its control. Food Nutr Bull 2004;25:S99204.

8. De Benoist B, Darnton-Hill I, Davidsson L, Fontaine O, Hotz C. Conclusions of the Joint WHO/UNICEF/ IAEA/IZiNCG Interagency meeting on zinc status indicators. Food Nutr Bull 2007;28(3 Suppl):S480-4.

9. Shakur MS, Malek MA, Bano N, Rahman M, Ahmed M. Serum and hair zinc in severely malnourished Bangladeshi children associated with or without acute lower respiratory infection. Indian J Pediatr 2009;76(6):60914.

10. Kumar S, Awasthi S, Jain A, Srivastava RC. Blood zinc levels in children hospitalized with severe pneumonia: a case control study. Indian Pediatr 2004;41:48691.

11. Brown KH, Peerson JM, Baker SK, Hess SY. Preventive zinc supplementation among infants, preschoolers, and older prepubertal children. Food Nutr Bull 2009;30(1 Suppl):S12-40.

12. Bates CJ, Evans PH, Dardenne M, Prentice A, Lunn PG, Northrop-Clewes CA, et al. A trial of zinc supplementation in young rural Gambian children. Br J Nutr 1993;69(1):243-55.

13. Muller O, Garenne M, Reitmaier P, Van Zweeden AB, Kouyate B, Becher H. Effect of zinc supplementation on growth in West African children: a randomized double-blind placebo-controlled trial in rural Burkina Faso. Int J Epidemiol 2003;32(6):1098-102.

14. Abiodun OA. Summary of workshop on clinical experience of micronutrient deficiency in children 0-5 years in Nigeria delivered at the 39th Paediatric Aociation of Nigerian Conference, Lagos 2008:1-64.

15. Araoye MO. Subjects Selection. In: Araoye MO, editor. Research methodology with statistics for health and social sciences. 1st ed. Ilorin: Natadex 2003:115 - 21.

16. Oyedeji GA. Socio-economic and cultural background of the hospitalized children in Ilesha Niger J Paediat 1985;12:111-17.

17. Hess SY, Peerson JM, King JC, Brown KH. Use of serum zinc concentration as an indicator of population zinc status. Food Nutr Bull 2007;28(3 Suppl):S403-29.

18. Bioassay Systems QuantiChrom ${ }^{\mathrm{TM}}$ zinc assay kit 
pamphlet on summary and explanation. Hayward,CA, USA:2007. www.bioassaysys.com

19. Johnson 'WBR Aderele WI, Osinusi K, Gbadero D, Fagbami A, Rotowa NA. Acute bronchiolitis in tropical Africa: a hospital-based perspective in Ibadan, Nigeria. Pediatr Pulmonol 1996;22(4):236-47.

20. Rudan I, Boschi-Pinto C, Biloglav Z, Mulholland K, Campbell H. Epidemiology and etiology of childhood pneumonia. Bull WHO 2008;86:412-16.

21. Annual Morbidity/ Mortality Statistics for the Emergency Paediatric Unit. 3rd ed. Ilorin: Department of Paediatrics, UITH, 2008.

22. Olaogun A, Ayoola A, Ogunfowokan A, Ewere V. Preference for the male child and desired family size in Nigeria. Afr J Midwiv Wom Hlth 2009;3:193-7.

23. Bhan G, Bhandari N, Taneja S, Marzumder S, Bahl $\mathrm{R}$, Other members of the Zinc Study Group. The effect of maternal education on gender bias in seeking care seeking for common childhood illnesses. Soc Sci Med
2005;60:715-24.

24. Ahmed S, Ahmed A, Chowdhury M, Bhuiya M. Gender, socio-economic development and health-seeking behaviour in Bangladesh. Soc Sci Med 2000;51:36173.

25. Bahl R, Bhandari N, Hambidge KM, Bhan MK. Plasma zinc as a predictor of diarrheal and respiratory morbidity in children in an urban slum setting. Am J Clin Nutr 1998;68(2 Suppl):414S-17S.

26. Maziya-Dixon B, Akinyele I O, Oguntona EB, Nokoe S, Sanusi R.A, Harris E. Nigeria Food Consumption and Nutrition Survey, 2001-2003 Summary. Ibadan: International Institute of Tropical Agriculture (IITA). 2004:27-59.

27. Krebs NF, Hambidge KM. Trace elements. In: Walker WA, Watkins JB, Duggan C, editors. Nutrition in Pediatrics: Basic Principles and Clinical Applications. 4th ed. Hamilton, Ontario: BC Decker Inc, 2008:6782. 